\title{
XIV. On the use of fluor-spar in optical instruments
}

\section{Professor Silvanus P. Thompson D.Sc., \&c.}

To cite this article: Professor Silvanus P. Thompson D.Sc., \&c. (1891) XIV. On the use of fluor-spar in optical instruments, Philosophical Magazine Series 5, 31:189, 120-123, DOI: 10.1080/14786449108620084

To link to this article: http://dx.doi.org/10.1080/14786449108620084

$$
\text { 曲 Published online: } 08 \text { May } 2009 .
$$

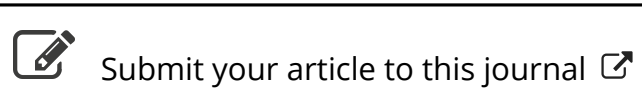

Џلl Article views: 2 
If it is an earth which is required, why not endeavour to fractionate alumina, an earth which, though resembling other earths of its class, to a certain extent is yet in many of its properties totally distinct from them? Again, if it is thought possible, were suitable means known to fractionate any element, why not endeavour to do so in the case of iodine? This element, being situated at the extreme end of its series, differs as much as it could possibly do from cresium, the element next to it in order of atomic weights. If, therefore, it were possible to separate iodine into bodies with atomic weights approaching gradually to that of cesium, might it not be thought that a very slight difference of atomic weight would correspond to a very much larger variation in chemical properties?

The actual fact of there being such a large number of these rare earths so very similar in properties is to be partly explained by the fact that not only these elements, but also the other members composing the table, show extreme variations among themselves to a smaller and smaller extent as their atomic weights get larger and larger. Also all these elements, except samarium and mosandrium, find their places in the third, fourth, and fifth groups, and are on this account naturally to a certain extent similar in properties.

It is hoped that in this paper the views and actual results of any chemist have not been misinterpreted. It has been endeavoured as far as possible to be correct, but if any slight errors have been committed, it is hoped that they will be recognized as being unintentional.

The University Laboratory, Oxford.

XIV. On the Use of Fluor-Spar in Optical Instruments. $B y$ Professor Siluanus P. Thompson, D.Sc., \&c.*

CONSIDERING the very distinctive optical properties of fluor-spar, it is remarkable that hitherto so little use has been made of it in the optical industries. Its low refractive power, and its still lower relative dispersion, make it remarkable amongst transparent media ; the only substances comparable with it in these respects being rock-salt and rockalum, both of which being soluble in water are for that reason

* Communicated by the Author, having been read before Section A of the British Association at Leeds. 
unfitted for use in optical instruments. Like these substances also, fluor-spar is optically isotropic, belonging to the cubic system of crystals.

The crystals of fluor-spar most usually occurrent in this country are by no means colourless, being generally purplish in tint, and exhibiting at the surface nearest to the light a fine fluorescence. Another variety, known as chlorophane, is of a pale green tint. Pure colourless crystals have also been found in Cornwall and in Switzerland; but these are now rather rare.

Lenses and prisms of fluor-spar have been from time to time used, instead of those made of rock-salt, for experiments on radiant heat; and, indeed, until recently this was the only optical application of this material.

Recently, however, fresh attention has been drawn to the subject by the announcement from the pen of Prof. Abbe, of Jena, that it is by the use of fluor-spar in combination with various sorts of glass that the well-known firm of Zeiss have been enabled to construct the remarkable microscope-objectives known as "apochromatic" lenses. These lenses were for long supposed-in spite of much scepticism on the part of opticians-to owe their excellent resolving power to the use of the new kinds of optical glass produced in Jena by Dr Schott. The secret, which was remarkably well kept for several years, is now revealed. Triplet lenses, somewhat like a Steinheil lens, with a fluor cemented between two outer lenses of glass, are used to correct the aberrations of the front lenses of glass. The peculiar value of the fluor lens for this purpose lies in its possession, alluded to above, of a singularly low dispersive power. According to Abbe the refractive index of the colourless fluor for sodium light is $1 \cdot 4338$, and for the hydrogen lines $\mathrm{C}$ and $\mathrm{F}$ the respective indices differ only by 0.00455 . For the sake of comparison with other materials, it is convenient (following Abbe) to consider the quantity

$$
\frac{\mu_{\mathrm{F}}-\mu_{\mathrm{C}}}{\mu_{\mathrm{D}}-1}
$$

as a measure of the specific power of any material to produce dispersion. Now, for ordinary crown-glasses, this quantity is about 0.0166 ; for dense flint as much as 0.019 ; for the special phosphate crown-glasses made at Jena it is as low as 0.0143 ; while for fluor-spar it is only 0.0104. As Abbe points out, the possession of this property enables the instrument-maker, by substituting fluor for crown-glass, to produce 
an achromatic lens, consisting of flint glass and fluor-spar, having faces of lesser curvature than would be requisite for a lens made of crown-glass with the same sort of flint. This is obviously a great advantage, as both the spherical aberration and the chromatic differences of the spherical aberration are reduced when the curvatures are lessened. Hence the use of fluor-spar for the construction of the improved achromatic lenses may be regarded as an application of this material of considerable importance.

1 have now the honour of announcing a third application of fluor-spar; namely to the construction of direct-vision prisms for spectroscopic purposes. The very same considerations which render fluor superior to crown-glass for achromatizing lenses render it, by an inverse use of the material, superior to crown-glass for the purpose of procuring, along with prisms of dense flint, a wide dispersion. A directvision prism made of one wide-angled prism of dense flintglass between two prisms of fluor has as great a dispersionpower as an ordinary five-prism combination of alternate crowns and flints. Such a prism, construeted for me by $\mathrm{Mr}$. C. D. Ahrens, a few months ago, shows extremely good definition. It is of course shorter than an ordinary crownflint combination of equal power, and requires fewer surfaces to be worked optically true.

When talking over this prism with Mr. Ahrens, he made the remark that it would now be possible to construct a directvision prism wholly without glass. This suggestion has since borne fruit; and enables me to present to the Section a small piece of apparatus which I believe is an entire optical novelty, namely a spectroscope which also polarizes the light. It consists simply of three prisms cemented together, like an ordinary direct-vision prism ; the two end prisms being of fluor-spar, and the middle prism of Iceland spar. The latter is cut (as in the improved Nicol prisms which I have on two former occasions described at meetings of the British Association) so that the crystallographic axis of the spar lies at right angles to the line of vision. The combination, which was constructed by Mr. Ahrens, acts therefore both as a Nicol prism and as a direct-vision prism. It is intended to be employed in spectrophotometric measurements.

For the purpose of direct-vision prisms the fluor-spar employed must be of the colourless kind, as a considerable thickness of it is necessarily interposed in the path of the light. That which Mr. Ahrens has cut for me is almost colourless, having a feeble green tinge. The combined prism 
of fluor and Iceland spar is far less absorbent than the directvision prisms ordinarily made with dense flint glass of a strong yellow tinge. For the purpose of achromatizing lenses the presence of a greenish or purplish tinge is of less importance, as a smaller thickness is used : and the purple fluorescence, which is objectionable in some ways, will not trouble the performance of the lens for any but photographic service.

It is of importance to note that the tint, whether purplish or greenish, of fluor-spar may be greatly reduced or nearly removed by simply heating the spar to a temperature a little above that at which it emits light in a darkened room. Care is necessary, however, that the crystals should not be heated either so suddenly or to so high a temperature as to cause decrepitation. Another point of even greater importance in the optical applications of fluor-spar is the selection of crystals which are not macled. Macled crystals of fluor seldom fail to show, when cut, some trace of double refraction which would unfit them for optical purposes.

The refractive index of the pale green variety seems to be a little higher than that of the colourless spar. I find $1 \cdot 435$ as the sodium-light index of refraction, as against 1.4338 found by Dr. Abbe.

City and Guilds Technical College,

Finsbury, September 3, 1890.

XV. On the Alternating Electric Are betueen a Ball and Point. By Edward L. Nichols*.

\section{Part I. $†$}

7 HE phenomenon which forms the subject of this paper 1 was first brought to my notice by Mr. E. G. Acheson, the result of whose unpublished observation may be briefly stated as follows:-

Two wires, which formed the terminals of the secondary coil of an alternating-current transformer, were brought nearly into contact. One wire was armed with a ball, the other with a point. When the distance was such as to admit of a discharge between the two, it was found that a galvanometer in shunt around the ball and point indicated a considerable flow of continuous current.

This phenomenon has recently been subjected to investiga-

* From Silliman's American Journal of Science, January 1891.

$\dagger$ From experiments made by Messrs. W. K. Archbold and G. L. Teeple. 